\title{
HAMMOND MEMORIAL LECTURE
}

\section{Are follicular maturation and oocyte maturation independent processes?}

\author{
C. Thibault \\ Physiologie de la Reproduction, Université de Paris VI and I.N.R.A., \\ 78350 -Jouy-en-Josas, France
}

I wish to thank the members of the John Hammond Memorial Committee for their kind invitation to deliver this lecture, which expresses very personal feelings. When, in 1949, as a recently graduated Ph.D. from the University of Paris, I was seeking my future orientation in research, I had the good luck to be in Ghent when John Hammond presented a prospective survey of the improvement of fertility in domestic animals by hormonal treatment. Some months later, I visited Hammond's laboratory in Cambridge and studied his books and papers on reproduction in the cow and rabbit. Today, looking back over the past 26 years, $I$ have the feeling that my work as a scientist, and as a Professor, found much of its inspiration in Hammond's thought and teaching.

I have chosen to speak today on the maturation of the female gamete because I consider that improvement in the availability of the female gamete in mammals remains the main objective of research related to animal production and the treatment of human infertility. Calves may be born after intracervical insemination with as few as 25,000 living spermatozoa, and in 3 years one bull may sire approximately 10 million calves; the cow, during the same 3 years, gives birth to three calves, or could be responsible for about a dozen calves if egg-transfer techniques are used.

The dream of maturing at will the thousands of oocytes in the ovary is certainly not realizable at present. Hormonally induced superovulation remains a lottery, and individual responses in sheep and cattle, as shown by John Hammond and his students, are highly variable. During the past 10 years there have been many papers on follicular development and oocyte growth and maturation, but authors have failed to mention the ability of experimental oocytes to continue normal development. My present intention is therefore to shed some light on the gaps in our knowledge of these vital processes.

\section{Maturation of the follicle and oocyte of lower vertebrates}

In lower vertebrates, as in mammals, the first steps of follicle and oocyte growth are almost completely independent of gonadotrophins or steroids. In hypophysectomized fish, oogonia will enter meiotic prophase. Goldfish ovarian fragments cultured without hormones show mitosis, meiotic prophase and previtellogenesis (Remacle. Delaere \& Jacquet, 1976).

Later, gonadotrophins are essential for the stages from vitellogenesis to ovulation. They become detectable in the blood at the beginning of vitellogenesis and culminate around the ovulation period with plasma levels 10-100 times higher than during the anovulatory period (Crim, Mayer \& Donaldson, 1973; Crim, Watts \& Evans, 1975). There is apparently a gonadotrophin surge in the female similar to that which is known to occur in higher vertebrates before ovulation (Breton, Billard, Jalabert \& Kann, 1972). Gonadotrophic action is mediated through steroids. In fish and amphibians, oocytes removed from their follicles do not resume meiosis spontaneously in culture. Steroids are necessary to initiate germinal vesicle breakdown (GVB), and there is some evidence of species specificity for progestagens, as shown in Tables 1 and $2.17 \alpha, 20 \beta$-Hydroxyprogesterone has been shown to be the most potent progestin in pike, trout and goldfish (Jalabert, 1976). In amphibians it has been accepted that progesterone is the more active progestin. However, the concentrations of progesterone necessary to induce $100 \%$ GVB in the frog (Schuetz, 1972) are also able to induce GVB 
Table 1. Maturation of fish oocytes (trout, pike and goldfish) in vitro by progestins

\begin{tabular}{lcccc}
\hline \multicolumn{1}{c}{ Steroid } & $\begin{array}{c}\text { Conc. } \\
(\mathrm{ng} / \mathrm{ml})\end{array}$ & $\begin{array}{c}\text { GVB } \\
(\%)\end{array}$ & $\begin{array}{c}\text { Conc. } \\
(\mathrm{ng} / \mathrm{ml})\end{array}$ & $\begin{array}{c}\text { GVB } \\
(\%)\end{array}$ \\
\hline Progesterone & 125 & 5 & - & - \\
17 $\alpha$-Hydroxyprogesterone & 125 & 30 & $12 \cdot 5$ & 0 \\
$20 \beta$-Hydroxyprogesterone & 125 & 100 & $12 \cdot 5$ & 10 \\
$17 \alpha, 20 \beta$-Hydroxyprogesterone & 125 & 100 & $12 \cdot 5$ & 100 \\
\hline
\end{tabular}

From Fostier et al., 1973; Jalabert, 1976.

Table 2. Maturation of amphibian oocytes in vitro by steroids

\begin{tabular}{|c|c|c|c|c|c|}
\hline Species & Steroid & $\begin{array}{l}\text { Conc. } \\
(\mathrm{mol} / \mathrm{l})\end{array}$ & $\begin{array}{l}\text { GVB } \\
(\%)\end{array}$ & $\begin{array}{l}\text { Conc. } \\
(\mathrm{mol} / 1)\end{array}$ & $\begin{array}{c}\text { GVB } \\
(\%)\end{array}$ \\
\hline \multirow[t]{4}{*}{ *Frog } & Progesterone & $10^{-6}$ & 93 & $10^{-7}$ & 68 \\
\hline & $5 \alpha$-Pregnane-3,20-dione & $10^{-6}$ & 83 & $10^{-7}$ & 46 \\
\hline & $3 \alpha, 3 \beta, 5 \alpha$-Pregnane-20-one & $10^{-6}$ & 70 & $10^{-7}$ & 3 \\
\hline & & $\begin{array}{l}\text { Conc. } \\
\text { (ng/ml) }\end{array}$ & $\begin{array}{l}\text { GVB } \\
(\%)\end{array}$ & $\begin{array}{l}\text { Conc. } \\
(\mathrm{ng} / \mathrm{ml})\end{array}$ & $\begin{array}{l}\text { GVB } \\
(\%)\end{array}$ \\
\hline \multirow[t]{4}{*}{$\dagger$ Xenopus } & Progesterone & 100 & 93 & 10 & 14 \\
\hline & Testosterone & 100 & 100 & 10 & 38 \\
\hline & Aldosterone & 100 & 100 & 10 & 100 \\
\hline & & $\begin{array}{c}\text { Conc. } \\
\text { (pmol/oocyte) }\end{array}$ & $\begin{array}{l}\text { GVB } \\
(\%)\end{array}$ & & \\
\hline \multirow[t]{4}{*}{$\ddagger$ Xenopus } & Progesterone & 1 & 10 & & \\
\hline & & 3 & 38 & & \\
\hline & . & 10 & 68 & & \\
\hline & & 30 & 91 & & \\
\hline
\end{tabular}

* From Sanyal \& Sibre (1975).

$\dagger$ From Jacobelli et al. (1974).

$\ddagger$ From Bellé et al. (1976).

in fish, and $17 \alpha, 20 \alpha$ - or $17 \alpha, 20 \beta$-hydroxyprogesterone is one of the main metabolites of progesterone in the Xenopus oocyte (Thibier-Fouchet, Mulner \& Ozon, 1976). Thus, 17 $\alpha, 20 \beta$-hydroxyprogesterone is perhaps the common final activator of fish and amphibian oocytes.

Membrane, cytosolic or nuclear progestin receptors have not been isolated from amphibian oocytes. Progestins penetrate the egg membrane and fix on peripheral pigment granules, the melanosomes (Ozon \& Bellé, 1973; Jacobelli, Hanocq, Baltus \& Brachet, 1974). It would seem that gene transcription is not involved because actinomycin $D$ does not prevent GVB.

As in mammals, prostaglandins (PG) E-2 and F-2 $\alpha$ are synthesized during follicular maturation and PGF-2 $\alpha$ plays an active role in the ovulation process (trout: Jalabert \& Szöllösi, 1975).

Since all these studies have been done in vitro and the results are therefore indisputable, it is tempting to postulate that steroid-dependent maturation of the oocyte is a general rule for vertebrates. However, physiological events related to oocyte maturation are so different in lower and higher vertebrates that this hypothesis cannot be accepted without critical analysis. Of these differences, the absence of intraovarian interaction between compartments with different steroidogenic activities, as is the rule in birds and mammals, may be mentioned.

Finally, we must remember that the biological endpoint which is usually taken is GVB. However, normal embryos do result from fertilization of in-vitro progestin-matured oocytes (Rana pipiens: Smith, Ecker \& Subtelny, 1968; Xenopus: Brun, 1975; trout : B. Jalabert, personal communication). 


\section{Maturation of follicle-free oocytes in mammals}

Oocytes from all the mammalian species studied are able to resume meiosis from the dictyate stage to metaphase II when cultured in a suitable medium (Table 3). Metabolic by-products from the cumulus cells are not involved in the initiation of maturation in vitro since cumulus-free oocytes also undergo maturation to metaphase II (rat: Zeilmaker \& Verhamme, 1974; mouse: Cross, 1973). It is clear from many studies (Table 3) that while the majority of the oocytes resume meiosis, as indicated by GVB, only a variable proportion reach metaphase II. This general observation has stimulated many attempts to discover, among polypeptide and steroid hormones, prostaglandins and cyclic AMP, those which induce the resumption of meiosis. This type of screening does not necessarily yield any valuable conclusions (Jagiello, Ducayen, Miller, Graffeo \& Fang, 1975).

Table 3. In-vitro maturation of extra-follicular oocytes in mammals

\begin{tabular}{lcccl}
\hline \multicolumn{1}{c}{ Species } & $\begin{array}{c}\text { Duration of } \\
\text { culture } \\
(\mathrm{h})\end{array}$ & $\begin{array}{c}\text { GVB } \\
(\%)\end{array}$ & $\begin{array}{c}\text { Oocytes in } \\
\text { metaphase II }\end{array}$ & \multicolumn{1}{c}{ Reference } \\
\hline Mouse & $?$ & 94 & 85 & Sorensen \& Wassarman, 1976 \\
Mouse & 17 & 94 & 88 & Donahue, 1968 \\
Mouse & 18 & 91 & 67 & Erickson \& Sorensen, 1974 \\
Rat & 17 & 98 & 83 & Erickson \& Ryan, 1976 \\
Guinea-pig & $20-24$ & 90 & 68 & Yanagimachi, 1974 \\
Hamster & 12 & $?$ & $90-95$ & Haidri \& Gwatkin, 1973 \\
Rabbit & 9 & 100 & 100 & Thibault \& Gérard, 1971 \\
Pig & $43-48$ & 88 & 80 & Tsafriri \& Channing, 1975a, b \\
Cattle & $29-30$ & 96 & 73 & Shea et al., 1976 \\
Cattle & 48 & 100 & 60 & Cho \& Lim, 1975 \\
Cattle & 29 & 100 & $91(\mathrm{M} 1)$ & Hunter et al., 1972 \\
Cattle (calf) & 29 & 100 & 97 & Thibault et al., 1975b \\
Sheep & 40 & $?$ & 91 & Quirke \& Gordon, 1971 \\
Dog & 48 & $?$ & $22 \cdot 5(\mathrm{M} 1+\mathrm{M} 2)$ & Mahi \& Yanagimachi, 1976 \\
Macaque & $46-48$ & 72 & 55 & Suzuki \& Mastroianni, 1966 \\
Macaque & $23-31$ & 50 & 23 & Jagiello et al., 1975 \\
Macaque & $29-36$ & 55 & 10 & Thibault et al., 1977 \\
Man & 42 & 43 & 31 & Shea et al., 1975 \\
Man & $43-47$ & 51 & 41 & Kennedy \& Donahue, 1969 \\
Man & $42-49$ & 45 & 42 & Jagiello et al., 1975 \\
\hline & & & & \\
\hline
\end{tabular}

In fact, three situations involving specific oocyte stages have been used. Firstly, in the juvenile female, maximum oocyte size is much less that that in pubertal and adult animals (man: LinternMoore, Peters, Moore \& Faber, 1974; hamster: Iwamatsu \& Yanagimachi, 1975; mouse: Szybek, 1972; Sorensen \& Wassarman, 1976). The oocytes from juvenile mammals are generally incompetent to resume meiosis, even if they come from antral follicles (hamster: Iwamatsu \& Yanagimachi, 1975; macaque: Gould \& Graham, 1976).

Secondly, all oocytes collected in preovulatory follicles, from either normal adults or PMSGpretreated prepubertal females, resume meiosis when culture conditions are favourable. Let us examine the criteria for an appropriate in-vitro environment. 'Suitable conditions' mean that not only must meiosis resume, but that the cumulus cells should continue to divide and pyknotic nuclei should not appear. As shown in Table 4, oxygen requirements differ somewhat according to the species. The chronology of successive events should also be absolutely similar to that in vivo (Thibault \& Gérard, 1971; Thibault, Gérard \& Menezo, 1975a). Changes in plasma membrane microvilli and an increase in the number of cortical granules and multivesicular bodies are observed simultaneously in mouse oocytes maturing in vivo and in vitro (Merchant \& Chang, 1971). Studies to demonstrate the positive effect of hormones or mediators on the percentage of oocytes reaching metaphase II must be discarded if the conclusions are based on the abnormal behaviour of the control (untreated) oocytes. 
Table 4. Oxygen tension in vitro and first polar body (PB) formation in extrafollicular oocytes

\begin{tabular}{|c|c|c|c|c|c|}
\hline Species & $\begin{array}{c}\text { Oxygen } \\
(\%)\end{array}$ & Medium & $\begin{array}{c}\text { Osmotic } \\
\text { pressure } \\
\text { (mosmol) }\end{array}$ & $\begin{array}{c}\text { 1st PB } \\
(\%)\end{array}$ & Reference \\
\hline Hamster & $\begin{array}{r}5 \\
10 \\
20\end{array}$ & $\begin{array}{l}\text { GH2 } \\
\text { GH2 } \\
\text { GH2 }\end{array}$ & $\begin{array}{l}285-295 \\
285-295 \\
285-295\end{array}$ & $\left.\begin{array}{r}100 \\
18 \\
0\end{array}\right\}$ & Gwatkin \& Haidri, 1973 \\
\hline Hamster & 5 & GH2 & 310 & 90 & Iwamatsu \& Yanagimachi, 1975 \\
\hline Hamster & $\begin{array}{c}5 \text { or } 20 \\
\text { (under oil) }\end{array}$ & GH2 & 285 & $66-100$ & Plachot \& Mandelbaum, 1977 \\
\hline Rat & $\begin{array}{l}95 \text { then } 5 \\
0 \text { then } 5\end{array}$ & mKRB & & $\begin{array}{l}80 \\
68\end{array}$ & Zeilmaker et al., 1972 \\
\hline Rabbit & 20 & TC $199+$ FCS & 290 & 100 & Thibault \& Gérard, 1971 \\
\hline Cattle (calf) & $\begin{array}{r}20 \\
5\end{array}$ & $\begin{array}{l}\text { TC } 199+\text { FCS } \\
\text { TC } 199+\text { FCS }\end{array}$ & $\begin{array}{l}290 \\
290\end{array}$ & $\left.\begin{array}{r}95-100 \\
100\end{array}\right\}$ & Thibault et al., 1975b \\
\hline Pig & $\begin{array}{l}20 \\
45 \\
95\end{array}$ & TC $199+$ PS & ? & $\left.\begin{array}{l}53 \\
44 \\
37\end{array}\right\}$ & Tsafriri \& Channing, 1975a, b \\
\hline
\end{tabular}

GH2, Medium 2 of Gwatkin \& Haidri (1973); mKRB, modified Krebs-Ringer bicarbonate; FCS, fetal calf serum; PS, pig serum.

Finally, there is a third group of oocytes, collected from antral follicles of different sizes at any stage (usually unknown) of the ovarian cycle. (There is a close correlation between the capacity of the mouse oocyte to resume meiosis and the appearance of the antrum in the developing follicle (Erickson \& Sorensen, 1974). However, rat oocytes from preantral follicles can resume meiosis, but only up to metaphase I (Erickson \& Ryan, 1976).) The physiological and morphological heterogeneity of oocytes and cumulus cells (Swartz \& Schuetz, 1975) renders this material unsuitable for planning pertinent experiments unless steroids-gonadotrophin or prostaglandin-gonadotrophin pretreatments have been used to synchronize and stimulate the growth of a wave of antral follicles. We have used this technique extensively with success in the 3-month-old calf; all the oocytes achieved first metaphase during culture (Table 5). By contrast, only $20 \%$ of monkey oocytes collected in the early follicular phase reached metaphase II (Table 9), irrespective of the pretreatment or the amount of cumulus or cumulus and granulosa cells encompassing the oocyte during culture. This is perhaps a consequence of the long follicular phase in primates.

Table 5. Maturation of calf oocytes cultured in vitro for $30 \mathrm{~h}$

\begin{tabular}{|c|c|c|c|c|}
\hline \multirow{2}{*}{$\begin{array}{c}\mathrm{O}_{2} \text { tension } \\
(\%)\end{array}$} & \multirow{2}{*}{$\begin{array}{c}\text { Hormones } \\
\text { added }\end{array}$} & \multirow{2}{*}{$\begin{array}{l}\text { No. of } \\
\text { oocytes }\end{array}$} & \multicolumn{2}{|c|}{ Nuclear stage } \\
\hline & & & Metaphase I & Metaphase II \\
\hline 20 & None & 3 & 0 & 3 \\
\hline 20 & FSH or LH & 27 & 3 & 24 \\
\hline 20 & $\begin{array}{c}\text { FSH + LH } \\
\text { +oestradiol-17 }\end{array}$ & 38 & 2 & 36 \\
\hline 5 & $\begin{array}{c}\text { FSH }+ \text { LH } \\
\text { +oestradiol-17 } \beta\end{array}$ & 11 & 0 & 11 \\
\hline
\end{tabular}

From Thibault et al., 1975b.

We can conclude that preovulatory oocytes, or even oocytes from small antral follicles, resume meiosis spontaneously when isolated in culture in appropriate media (Menezo, 1976): hormones are not involved and final oocyte nuclear maturation in mammals is not follicle-dependent.

We now need to ask if nuclear maturation is the only event preparing the oocyte for further development; in other words, do other aspects of maturation need the presence of the follicle. It seems that in one species, the mouse, the extrafollicular oocyte can complete all aspects of its matu- 
ration in vitro, as shown by the presence of 15-day-old living fetuses (Cross \& Brinster, 1970) and the birth of young (Mukherjee, 1972) after complete maturation and fertilization in vitro before transfer to foster mothers. As far as I know, in-vitro maturation of extrafollicular oocytes in other species has not been followed by normal embryonic development (Sreenan, 1970). Depending on the species, this failure may be related to unfertilizability of the oocyte, delayed and incomplete sperm head swelling or abnormal protein synthesis.

\section{Fertilizability of the extrafollicular oocyte}

Recently, Plachot \& Mandelbaum (1977) have shown that hamster oocytes matured in vitro cannot be fertilized in vitro. A large proportion of preovulatory hamster oocytes resumed meiosis when they were cultured with their attached cumulus in the conditions described by Gwatkin \& Haidri (1974) (medium $\mathrm{GH} 2$, in paraffin oil, gas phase $=5 \% \mathrm{O}_{2}$ or air) and then mixed with epididymal spermatozoa, but fertilization had not occurred $24 \mathrm{~h}$ later. Tubal oocytes cultured with the same sperm sample were fertilized (Table 6). Inside the follicle, therefore, the zona pellucida had become sensitive to sperm enzymes, but it would not react if the oocyte had matured outside the follicle. Collection of oocytes at increasing times after HCG injection of the female shows that the capacity of the zona to be penetrated is acquired between 5 and $6 \mathrm{~h}$ after gonadotrophin injection (Table 7).

Table 6. Fertilization rates of hamster oocytes ovulated or matured in vitro (from Plachot \& Mandelbaum, 1977)

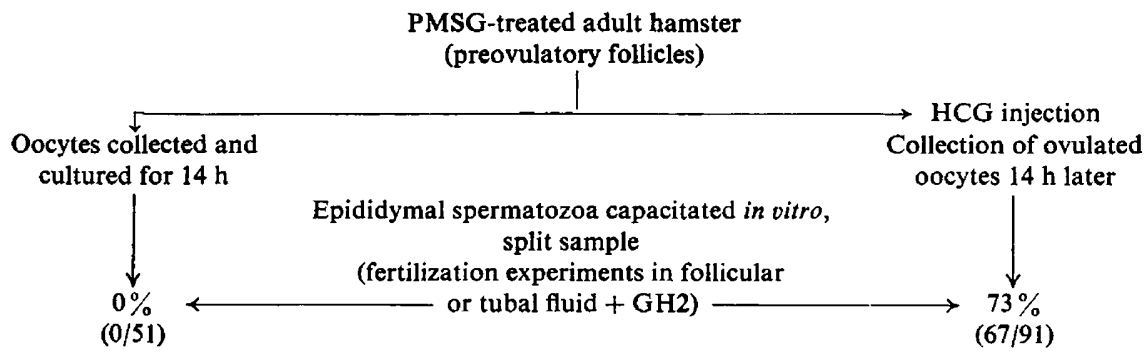

Table 7. Partial maturation in vivo and fertilization rates of hamster oocytes (from Plachot \& Mandelbaum, 1977), and rat oocytes (from Niwa \& Chang, 1975)

\begin{tabular}{|c|c|c|c|}
\hline Species & $\begin{array}{l}\text { Recovery after } \\
\text { HCG injection } \\
\text { (h) }\end{array}$ & $\begin{array}{l}\text { Duration of } \\
\text { complementary culture } \\
\text { with sperm. } \\
\text { (h) }\end{array}$ & $\begin{array}{l}\text { Fertilization } \\
\text { in vitro } \\
\text { (h) }\end{array}$ \\
\hline \multirow[t]{3}{*}{ Hamster } & 2 & 12 & $0(0 / 37)$ \\
\hline & 4 & 10 & $0 \quad(0 / 26)$ \\
\hline & 6 & 8 & $24(6 / 26)$ \\
\hline \multirow[t]{3}{*}{ Rat } & 6 & 4 & $7(8 / 108)$ \\
\hline & 8 & 4 & $52(46 / 89)$ \\
\hline & 10 & 4 & $72(46 / 89)$ \\
\hline
\end{tabular}

The data of Niwa \& Chang (1975) indicate to me that the rat oocyte must also remain in the follicle for 6 or $7 \mathrm{~h}$ before becoming fertilizable. However, these authors did not draw this conclusion (Table 7), and Niwa, Miyake, Iritani \& Nishikawa (1976) concluded that sperm penetration of oocytes matured in vitro from any stage of maturation was possible, although the final stage of fertilization was abnormal in oocytes recovered earlier than $6-8 \mathrm{~h}$ after $\mathrm{HCG}$. 


\section{Ability of extrafollicular oocytes to change the sperm head into male pronucleus}

In-vitro-matured oocytes from rabbits, pigs, cows and women can be penetrated by spermatozoa. However, a striking difference is visible between oocytes matured in vivo and in vitro: the male nucleus does not dissociate and swell immediately after penetration of in-vitro-matured oocytes as it does in freshly ovulated eggs. The sperm head remains unchanged for some hours, and when swelling does occur, grains of condensed chromatin remain in the male pronucleus. Finally, such eggs cleave but do not develop further (Thibault \& Gérard, 1970; Thibault \& Gérard, 1973; Soupart, 1973; Motlik \& Fulka, 1974a, b; Thibault et al., 1975a).

In the follicle in vivo the rabbit oocyte becomes able to assume immediate changes in sperm nucleus structure and composition only $6 \mathrm{~h}$ after an HCG injection or the postcoital LH surge (Thibault \& Gérard, 1973). It is striking that this delay is so similar to that necessary for hamster and rat oocytes to become fertilizable (Table 8); such oocytes acquire, in the follicle, both zona sensitivity to spermatozoa and the ability to assume sperm nucleus decondensation. Niwa \& Chang (1975) mention abnormality of sperm head transformation when rat oocytes were fertilized in vitro after removal from the follicle less than $6 \mathrm{~h}$ after the HCG injection. Usui \& Yanagimachi (1976), with no reference to previous studies and using zona-free oocytes, confirmed that the male pronucleus growth factor (MPGF) in hamsters only appears in vivo about $8 \mathrm{~h}$ after $\mathrm{HCG}$ injection.

Table 8. Partial maturation in vivo and sperm nucleus decondensation of rabbit oocytes (from Thibault \& Gérard, 1973)

\begin{tabular}{cccc}
\hline \multirow{2}{*}{$\begin{array}{c}\text { Time of recovery } \\
\text { after HCG }\end{array}$} & $\begin{array}{c}\text { Duration of } \\
\text { (h) }\end{array}$ & $\begin{array}{c}\text { Sperm head } \\
\text { change (\%) }\end{array}$ & \multicolumn{2}{c}{$\begin{array}{c}\text { spemaltare } \\
\text { chang }\end{array}$} & Abnormal & Normal \\
\cline { 3 - 4 } & 12 & 100 & 0 \\
3 & 12 & 100 & 0 \\
5 & 12 & 100 & 0 \\
7 & 5 & 20 & 80 \\
\hline
\end{tabular}

\section{Do gonadotrophins or steroids mediate these two aspects of oocyte maturation?}

Gonadotrophins act directly on cumulus cells (Thibault et al., 1975a; Hillensjö, Dekel \& Ahrén, 1976b), changing their metabolic pathways towards pyruvate and lactate formation, increasing the production of progesterone (Nicosia \& Mikhail, 1975), enhancing the synthesis of glycoproteins by the Golgi apparatus (Moricard, 1968) and probably breaking gap junctions. However, gonadotrophins are completely unable to promote cytoplasmic maturation of extrafollicular cumulus-enclosed oocytes, at least in experiments performed with rabbit, cow, hamster and human oocytes.

In contrast, some ovarian steroids, added to the culture to mimic the sequences and levels reached in vivo during final follicle maturation, can stimulate sperm nucleus decondensation in human and rabbit oocytes. The clearest results have been obtained for human oocytes by Soupart (1974); when oestradiol-17 $\beta$ and then 17 $\alpha$-hydroxyprogesterone were added during maturation of oocytes in vitro, decondensation of the sperm nucleus occurred immediately after fertilization.

In our studies, oestradiol and testosterone seem to have a similar action on rabbit eggs, but the results were not consistent (Thibault et al., 1975b).

Because cumulus-enclosed oocytes have been used, there is no evidence for or against a direct effect of steroids on the ooctye itself, as in amphibians. It is evident that only steroids and steroid levels found in the follicular fluid should be taken into consideration. We have recently shown that the LH surge or injection of HCG stimulates a rapid increase of progesterone production with a simultaneous drop in oestradiol in sow follicular fluid, although no increase of progesterone can be detected in the blood plasma (P. Rombauts \& J. Bertin, unpublished). 


\section{What happens in the follicle?}

From the preceding studies in vitro it appears that three main events occur in the oocyte during the preovulatory phase. These are resumption of meiosis, cytoplasmic maturation, and maturation of the oocyte membrane.

Culture of the intact follicle has been shown to be a useful method for studying follicular regulatory mechanisms of oocyte maturation. There is general agreement in the recent literature that when carefully dissected follicles are cultured, meiosis resumes in the intrafollicular oocyte if gonadotrophins are added to the culture medium (rat: Tsafriri, Lindner, Zor \& Lamprecht, 1972; Hillensjö et al., 1976b; hamster: Gwatkin \& Andersen, 1976; Mandelbaum, Plachot \& Thibault, 1977; cow: Thibault et al., 1975a, b; rabbit: Thibault \& Gérard, 1973; monkey: Thibault et al., 1976; sheep: Miller \& Jagiello, 1973; Moor \& Trounson, 1977; pig: Daguet, 1977).

Cytoplasmic and membrane maturation of the oocyte are also acquired during the culture of follicles in the presence of gonadotrophins. Hamster intrafollicular oocytes are fertilizable (Mandelbaum et al., 1977) and sperm head swelling is immediate in rabbit intrafollicular oocytes (Thibault \& Gérard, 1973). When fertilized, these oocytes develop normally up to the birth of normal young (Thibault et al., 1975a, b). Moor \& Trounson (1977) have recently described the birth of lambs from follicular oocytes recovered after culture of large antral sheep follicles in the presence of gonadotrophins. This shows that the antral follicle represents a physiological entity capable of supporting nuclear and cytoplasmic oocyte maturation in vitro.

Rat preovulatory follicles have been extensively used in studies on the mode of gonadotrophin action in vitro. Meiotic resumption occurs even if steroidogenesis is suspended by the addition of specific steroid inhibitors to culture media (Lieberman et al., 1976). Similarly, the enhancement and change in metabolic pathways induced by gonadotrophins are unrelated to activation of the oocyte nucleus (Lieberman, Ahrén, Tsafriri, Bauminger \& Lindner, 1975; Tsafriri, Lieberman, Ahrén \& Lindner, 1976; Hillensjö, 1976).

Unfortunately, no recent data are available for the effect of steroidogenic or metabolic blockade on cytoplasmic maturation of the oocyte. Similarly, we do not know if cyclic AMP and PGE-2 sustain both nuclear and cytoplasmic maturation. More refined criteria than GVB must be introduced in subsequent biochemical and molecular research.

\section{Follicular development and oocyte maturation}

In the two successful experiments mentioned above, the rabbit (Thibault et al., 1975a) and lamb (Moor \& Trounson, 1977) material consisted of oocytes from relatively large antral follicles. Such follicles are present in rather limited numbers in the ovary. It is tempting to induce a larger population of small or medium-sized follicles, but this poses many questions, such as: are these follicles also able to resume meiotic maturation; how can the ovary be induced to provide a physiologically homogeneous population of such follicles; and are present culture techniques suitable for a long prematuration phase in vitro, if necessary?

Studies on the principal cytological and biochemical characteristics of the follicle show that follicles of the same size may differ physiologically, mainly with the sexual cycle period. The nature of the steroids secreted in culture (sheep: Seamark, Moor \& McIntosh, 1974), FSH and LH titres in the follicular fluid vary (man: McNatty et al., 1975), depending on whether they are collected during the follicular or luteal phase. Thus, the prerequisite is the preparation of an homogeneous population of medium-sized follicles by hormonal treatment. We successfully use a sequential pretreatment on 3-month-old calves and adult macaques ( $M$. fascicularis). Basically, these animals receive repeated injections of progesterone followed by PMSG. The percentage of nonatretic follicles increases, and if ovaries are not removed after pretreatment, spontaneous superovulation occurs in the calf; a high pregnancy rate after mating for 2 days is the rule in the subsequent cycle of the macaque (Dang, 1975). 
From serial experiments developed with 3-4-mm calf follicles cultured by superfusion in synthetic medium (Menezo, Gérard \& Thibault, 1976b), in the presence of different combinations of gonadotrophins, we observed that only one-third of the oocytes reached metaphase II and that cumulus cell dissociation seldom occurred. This gonadotrophic response is constant in vivo after an LH surge or in preovulatory follicles cultured with gonadotrophin (pig: Daguet, 1977; rat: Hillensjö et al., 1976b; rabbit: Thibault et al., 1975a). Moreover, control culture experiments of extrafollicular oocytes recovered from the same follicular population show both nuclear maturation and a beautiful gonadotrophic reaction of the corona cells. The lack of response when the oocyte and its cumulus are left inside a medium-sized follicle may be due to insufficient penetration of gonadotrophin or more probably to absence of LH receptors, so that the inhibitory control of granulosa cells on the oocyte and cumulus cells is not turned off.

In the macaque, however, control extrafollicular oocytes show the same behaviour as intrafollicular oocytes; many of them remain either at the dictyate stage or in prometaphase and corona cell dissociation is rare and irregular (Table 9). More refined criteria than follicle size must be used for assessment of a physiologically homogeneous follicle population. In the macaque, the incompetence of oocytes from antral follicles, at least during the early follicular phase, raises the question of the importance of changes in the dictyate nucleus before the resumption of meiosis becomes possible. It has been shown in the urodele, Notophthalmus viridescens (Barsacchi-Pilone \& Humphries, 1975), that shortening of the lampbrush chromosomes, contraction of the chromosomes and nucleoli in the central part of the germinal vesicle, together with migration of the germinal vesicle to the oocyte periphery, necessarily precede meiotic resumption. These processes do not depend on progesterone but are gonadotrophin-dependent. In the carp, the migration of the germinal vesicle to the periphery of the oocyte is also gonadotrophin-dependent, and $17 \alpha, 20 \beta$-hydroxyprogesterone is unable to induce meiotic resumption in oocytes which have not been primed with gonadotrophins (Jalabert, Breton, Brzuska, Fostier \& Wieniawski, 1977).

Table 9. Maturation of macaque oocytes in vitro

\begin{tabular}{lcccccc}
\hline & Total & $\begin{array}{c}\text { Dictyate } \\
\text { nucleus }\end{array}$ & MR* & MI & MII & $\begin{array}{c}\text { MI + MII } \\
\%\end{array}$ \\
\hline $\begin{array}{c}\text { Extrafollicular } \\
\text { oocytes }\end{array}$ & 103 & 42 & 17 & 23 & 21 & 43 \\
$\begin{array}{c}\text { Intrafollicular } \\
\text { oocytes }\end{array}$ & 16 & 4 & 2 & 5 & 5 & 60 \\
\hline
\end{tabular}

* Meiotic resumption, early chromosome formation before GVB.

Observations of calf, pig and macaque germinal vesicles seem to show the same preparation of the dictyate nucleus before meiotic resumption can occur. Five days before oestrus in the pig, oocytes in the largest healthy follicles show a typical dictyate nucleus; on the following days the lampbrush loops disappear and condensed chromatin masses progressively aggregate around the central nucleolus. The germinal vesicle reaches the oocyte periphery (Daguet, 1977). This final event has been described by Hunter \& Polge (1966) and by Motlik \& Fulka (1976) in pro-oestrous sows. It must be remembered that oocytes which are ovulated after HCG injection on Day 17 of the cycle remain in the dictyate stage (Hunter, Cook \& Baker, 1976), and this probably means that germinal vesicle change is a prerequisite for resumption of meiosis.

In calves treated with gonadotrophins, oocytes in 3-4-mm follicles are at different stages of germinal vesicle maturation, even up to the time of disappearance of the nucleolus. It is tempting to correlate this heterogeneity with the variable rate of meiotic resumption when such follicles are cultured with gonadotrophins. In macaques treated with gonadotrophins, oocytes in the largest follicles are always at exactly the same dictyate stage, and this perhaps correlates with a very low percentage of meiotic resumption in vitro (Thibault et al., 1978). 


\section{How follicular cycles in vivo can be understood}

Using data from the impressive amount of recent research in vivo and in vitro, I have attempted to make a general plan of the main mechanisms and hormonal interactions involved in follicle maturation and oocyte maturation in vivo (Text-fig. 1).

The simplest analyses can be drawn from rodents which have an ovarian cycle without a luteal phase. During pro-oestrus, the rise of oestradiol to a level at least 10 times higher than the basal level has two effects. One, the induction of a gonadotrophin surge, is classical; the other (generally omitted), is the stimulation of a population of preantral follicles by increasing the mitotic rate of granulosa and theca cells (Goldenberg, Vaitukaitis \& Ross, 1972; Louvet \& Vaitukaitis, 1976) and by multiplying the number of gap junctions between granulosa cells (Merk, Botticelli \& Albright, 1972; Albertini, Fawcett \& Olds, 1975; Anderson \& Albertini, 1976). These next permit passage of cyclic AMP from one cell to the other so that activation of the adenyl cyclase system in a peripheral cell may induce a general response of all the granulosa cells. Subsequently, on Day 1 the FSH surge occurs without an LH surge, and it has been beautifully shown for the hamster that there is a close relationship between the level of FSH (or FSH-like PMSG) at this time and the number of preantral follicles forming antra (Greenwald, 1974; Bast \& Greenwald, 1974).
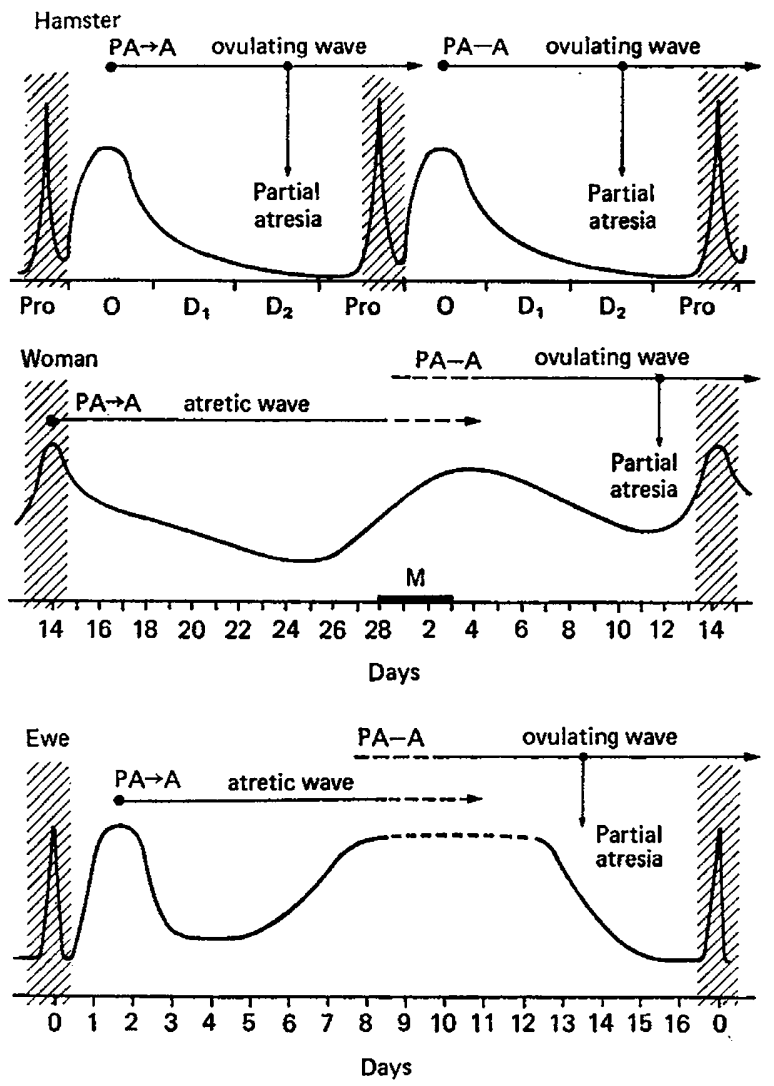

Text-fig. 1. Probable origin and fate of the main follicular waves occurring during the female cycle as related to FSH levels. Hamster FSH from Bast \& Greenwald (1974), Bex \& Goldman (1975); human FSH from Wide et al. (1973); sheep FSH from L'Hermite et al. (1972), Salamonsen et al. (1973), Hopkinson \& Pant (1973), Pant et al. (1977). The FSH variations of pseudopregnant rats (Welschen et al., 1975) are similar to those observed in sheep. The hamster follicular waves are according to Greenwald (1974) and Bex \& Goldman (1975); the human and sheep follicular wave are as suggested in the present paper. PA $\rightarrow$ A, transition of preantral to antral follicles; __ , FSH changes; hatched area, LH surge. Pro, pro-oestrus; $O$, oestrus; $D_{1}, D_{2}, 1$ st and 2 nd day of dioestrus; $M$, menstruation. 
The only role for the FSH surge is the stimulation of preantral oestrogen-primed follicles; antiFSH serum given on the day of pro-oestrus does not prevent ovulation but postpones formation of antral follicles. By contrast, when an antiserum to LH is given in the same conditions, neither ovulation nor meiotic resumption occur but antral follicles develop (rat: Welschen \& Dullaart, 1976). During the following 2 days, FSH levels progressively descend to reach a nadir on the morning of the next day of pro-oestrus (Bast \& Greenwald, 1974; Bex \& Goldman, 1975), probably because of the cumulative effects of oestradiol and an inhibin-like substance from the growing follicles.

At this time, FSH levels are insufficient to support all preovulatory follicles. If the FSH level is increased artificially by hemicastration or FSH injections to intact animals, atresia is partly prevented, and a higher ovulation rate per ovary follows (rat: Welschen, 1972; Welschen \& Dullaart, 1974; hamster: Greenwald, 1962; Grady \& Greenwald, 1968; Bex \& Goldman, 1975). According to our observations of atresia in vitro, we think that the main role of FSH at this critical period is to facilitate increased metabolic exchange, either directly or via oestradiol secretion.

FSH also induces the formation of LH receptors in granulosa cells, and the number of receptors increases tremendously during final growth of the follicle (Channing \& Kammerman, 1974; Zelesnik, Midgley \& Reichert, 1974). Oestradiol enhances this FSH effect and prepares granulosa cells to luteinize in response to the LH surge. In hypophysectomized rats, LH induces luteinization or atresia regardless of whether oestradiol is present (Richards \& Midgley, 1976).

The discovery of the importance of the high gonadotrophin level during the preovulatory surge is fascinating. This high level is absolutely necessary for temporary desensitization of the adenyl cyclase system (rat: Zor, Lamprecht, Misulovin, Koch \& Lindner, 1976; rat, rabbit: HunzickerDunn \& Birnbaumer, 1976a, b). After a burst of steroidogenesis, consisting mainly of progesterone (Hillensjö, Bauminger \& Ahrén, 1976a) because LH secondarily initiates inhibition of 17-20 desmolase and $17 \alpha$-hydroxysteroid dehydrogenase, there is a general decrease in the steroid titre in the follicle before ovulation. We have shown previously that oestradiol, 17 $\alpha$-hydroxyprogesterone or testosterone play a role in the cytoplasmic maturation of human and rabbit oocytes. This is probably the main function of the temporary increase of intrafollicular steroids after the LH surge.

Studies of intrafollicular oocyte maturation in vitro have confirmed the importance of a high gonadotrophin level in the medium to prime GVB. Turning now to primates, it is clear that during the follicular phase, gonadotrophin profiles may be superimposed on those observed in rodents with short cycles. The only differences are the duration of the phase (4 versus 12 days) and the absence of high oestradiol levels preceding high FSH levels. It is suggested that the transition form the preantral to the antral stage in the 'wave' of ovulatory follicles occurs at the beginning of the follicular phase. Regulation of ovulation rate by atresia seems to take place 3 days before the LH surge (A. Gougeon, personal communication). It is probable that a secondary 'wave' of follicles is induced at mid-cycle after the oestradiol and FSH surges, and the resulting antral follicles undergo atresia before the next 'wave' of ovulatory follicles occurs.

Finally, if we look at the sparse data on domestic mammals, partial overlapping of the luteal and follicular phases renders analysis and comparison more difficult. The presence of a permanent population of variable-sized follicles at all stages of the cycle reflects the regular follicular outflow from the 'pool' of primordial follicles; this population obscures the real lineage of the ovulatory follicles. As we are unable to identify key mechanisms, I shall try to produce an hypothesis which fits the preceding description of events. As in rodents, the 'wave' of development of antral follicles occurs at oestrus as a result of an oestradiol-FSH surge. However, because the corpus luteum is active, stimulated follicles become atretic after a rise in oestradiol secretion before mid-cycle. Greater efficiency of PMSG-prostaglandin treatment at this time of the cycle seems to indicate that PMSG can 'rescue' such follicles.

It has been postulated that the preovulatory follicles are derived from the second 'wave' of growth which occurs at mid-cycle. This assumption has no experimental basis, although there are some supporting data for this hypothesis. If a relatively high level of FSH is the necessary gonadotrophic stimulus for the transition from preantral to antral follicle, the FSH profile in sheep during the oestrous cycle indicates that this stimulation can occur when FSH returns to high levels around Day 7-8 of the cycle, i.e. approximately 1 week before the gonadotrophin surge at oestrus. The titre 
of oestradiol in large follicles is also higher at this time than during the following days, and blood levels increase simultaneously. In the cyclic cow also, there are two periods of relatively high levels of FSH, at Days 4-9 and Days 16-21. However, it is not possible at present to establish any correlation between these profiles and waves of follicular growth, especially as the profiles differ profoundly from one cow to another (Schams \& Schallenberger, 1976). It is tempting to ask whether these variations are related to the different degrees of superovulation after PMSG treatment.

It is rather difficult to obtain morphological information from papers dealing with follicle populations during the cycle because most authors follow the fate of follicles larger than those of most interest, i.e. those in transition from the preantral to the antral stage which have a diameter of about 200-300 $\mu \mathrm{m}$ in sheep and cattle (see Hay \& Moor, 1975).

It has been shown that superovulation is induced in sheep when PMSG (Thibault, Ortavant \& Laplaud, 1948) or an LH-RH analogue (Findlay \& Cumming, 1976) is injected 3-4 days before oestrus. This increased ovulation rate may be attributed to the preservation of some preovulatory follicles which would otherwise have become atretic rather than to the stimulation of transition from the preantral to the antral stage; PMSG given 3-4 days before ovulation in ruminants would play the same role as PMSG treatment on the 2 nd day of dioestrus in the hamster. Recent observations on the pig which support this interpretation must be mentioned. After methallibure treatment, follicles grow for 5 days and then ovulate around Day 6. Atresia affects some of the growing follicles around Day 2 (Daguet, 1977), a situation very similar to that occurring on the evening of dioestrus 2 in the hamster. It is interesting to remember that Hunter et al. (1976) observed superovulation after a single HCG injection only when this hormone was given on Day 17 of the cycle. This would be equivalent to the time (2-3 days) after methallibure treatment before partial atresia began. It seems highly likely, therefore, that in domestic ruminants ovulatory follicles leave the preantral stage approximately 1 week before the oestrous LH surge, and that final regulation of ovulation rate takes place by atresia 3-4 days before oestrus.

\section{Conclusions}

As far as meiotic resumption is concerned, oocyte competence is acquired long before the preovulatory gonadotrophin surge, before antrum formation (rat: Erickson \& Ryan, 1976), immediately afterwards (mouse: Erickson \& Sorensen, 1974), or later on (pig: Hunter et al., 1976).

Competent oocytes resuming meiosis when isolated from the follicle are able to cleave after parthenogenetic activation (rabbit: Thibault, 1972; cow: Menezo el al., 1976a). However, protein synthesis does not change during oocyte meiotic resumption in vitro in the same way as it does intrafollicularly (Warnes, Moor \& Johnson, 1977).

When considering the ability of the oocyte to associate with the male gamete, to recognize its enzymes or to support its participation, it must be remembered that the oocyte remains dependent on the follicle almost up to the moment of follicle rupture. This role of the follicle is probably achieved in vivo by a classical sequential steroid action, when the LH surge dramatically changes the intrafollicular steroid content.

In the ovary, cyclic changes in oestradiol and FSH levels stimulate one or two waves of follicular growth. In vivo FSH and oestradiol play a major role in the regulation of ovulation rates (a) during the transition from the preantral to the antral stage and (b) some days before ovulation, when atresia reduces the number of preovulatory follicles. The ovulation of increased numbers of completely matured oocytes, or the preparation of a large population of $\mathrm{LH}$-sensitive follicles for maturation in vitro, needs a better understanding of follicular cycles. An approach is suggested in rodents, ruminants and primates.

\section{References}

Albertinı, D.F., FawcetT, D.W. \& Olds, P.J. (1975) Morphological variations in gap junctions of ovarian granulosa cells. Tissue Cell Res. 7, 389-405.
Anderson, E. \& Albertini, D.F. (1976) Gap junctions between the oocyte and companion follicle cells in the mammalian ovary. J. Cell Biol. 71, 680-686. 
Barsacchi-Pilone, G. \& Humphries, A.A. (1975) Progesterone induced in vitro maturation in oocytes of Notophthalmus viridescens (Amphibia, Urodela) and some observations on cytological aspects of maturation. J. Embryol. exp. Morph. 34, 451-466.

BAst, J.D. \& GREENWALD, G.S. (1974) Serum profiles of follicle-stimulating hormone, luteinizing hormone and prolactin during the estrous cycle of the hamster. Endocrinology 94, 1295-1299.

Belle, R., Marot, J. \& Ozon, R. (1976) Recherches sur la maturation de l'ovocyte de Xenopus laevis. L'entrée de la progestérone est nécessaire pour la maturation. C. r. hebd. Séanc. Acad. Sci., Paris 283, 175-178.

Bex, F.J. \& Goldman, B.D. (1975) Serum gonadotropins and follicular development in the Syrian hamster. Endocrinology 96, 928-933.

Breton, B., Billard, R., Jalabert, B. \& KanN, G. (1972) Dosage radioimmunologique des gonadotropines plasmatiques chez Carassius auratus au cours du nycthémère et pendant l'ovulation. Gen. comp. Endocr. 18, 463-468.

BRUN, R. (1975) Oocyte maturation in vitro: contribution of the oviduct to total maturation in Xenopus laevis. Experientia 31, 1275-1276.

Channing, C. \& Kammerman, S. (1974) Binding of gonadotropins to ovarian cells. Biol. Reprod. 10, 179-198.

Chо, W.K. \& Lim, K.J. (1975) Studies on the effects of follicular fluid and its fractions on the cow oocyte maturation in vitro. Korean J. Zool. 18, 61-70.

Crim, L.W., Mayer, R.K. \& Donaldson, E.M. (1973) Radioimmunoassay estimates of plasma gonadotropin levels in the spawning pink salmon. Gen. comp. Endocr. 21, 69-76.

Crim, L.W., Watrs, E.G. \& Evans D.M. (1975) The plasma gonadotropin profile during sexual maturation in a variety of salmonid fishes. Gen. comp. Endocr. 27, 62-70.

Cross, P.C. (1973) The role of cumulus cells and serum in mouse oocyte maturation in vitro. J. Reprod. Fert. 34, 241-245.

Cross, P.C. \& BRINSTER, R.L. (1970) In vitro development of mouse oocytes. Biol. Reprod. 3, 298-307.

Daguet, M.C. (1977) Some aspects of preovulatory follicle growth in pig. Annls Biol. anim. Biochim. Biophys. 17, (in press).

DANG, D.C. (1974) Maîtrise du cycle menstruel par la progestérone et fertilité chez Macaca fascicularis. $J$. Gynec, Obstet. Biol. Reprod. 3, 469-476.

Donahue, R.P. (1968) Maturation of the mouse oocyte in vitro. I. Sequence and timing of nuclear progression. J. exp. Zool. 169, 237-250.

Erickson, G.F. \& RYAN, K.J. (1976) Spontaneous maturation of oocytes isolated from ovaries of immature hypophysectomized rats. J. exp. Zool. 195, 153-158.

Erickson, G.F. \& Sorensen, R.A. (1974) In vitro maturation of mouse oocytes isolated from late, middle and preantral graafian follicles. J. exp. Zool. 190, 123-127.

FindLAy, J.K. \& Cumming, I.A. (1976) Increase in ovulation rate in sheep following administration of an LH-RH analogue. Biol. Reprod. 15, 115-117.
Fostier, A., Jalabert, B. \& Terqui, M. (1973) Action prédominante d'un dérivé hydroxylé de la progestérone sur la maturation in vitro des ovocytes de Truite arc en ciel (salmo gairdnerii). C. r. hebd. Séanc. Sci., Paris 277, 421-424.

GoldenberG, R.L., Vaitukaitis, J.L. \& Ross, G.T. (1972) Estrogen and follicle stimulating hormone interactions on follicle growth in rats. Endocrinology 90, 1492-1498.

Gould, K.G. \& GrahaM, C.E. (1976) Maturation in vitro of oocytes recovered from prepubertal rhesus monkeys. J. Reprod. Fert. 46, 269-270.

GreenwaLd, G.S. (1962) Temporal relationship between unilateral ovariectomy and the ovulatory response of the remaining ovary. Endocrinology 71, 664-666.

GreENWALD, G.S. (1974) Quantitative aspects of follicular development in the untreated and PMStreated cyclic hamster. Anat. Rec. 178, 139-144.

Grady, K.L. \& Greenwald, G.S. (1968) Studies on interactions between the ovary and pituitary folliclestimulating hormone in the golden hamster. $J$. Endocr. 40, 85-90.

Gwatkin, R.B.L. \& Andersen, O.F. (1976) Hamster oocyte maturation in vitro: inhibition by follicular components. Life Sci. 19, 527-536.

Gwatkin, R.B.L. \& HAIDRI, A.A. (1973) Requirements for the maturation of hamster oocytes in vitro. Expl Cell Res. 76, 1-7.

GWatkIN, R.B.L. \& HaidRI, A.A. (1974) Oxygen requirements for the maturation of hamster oocytes. J. Reprod. Fert. 37, 127-129.

HAIDRI, A.A. \& GWATKIN, R.B.L. (1973) Requirements for the maturation of hamster oocytes from preovulatory follicles. J. Reprod. Fert. 35, 173-176.

Hay, M.F. \& Moor, R.M. (1975) Functional and structural relationship in the Graafian follicle population of the sheep ovary. J. Reprod. Fert. 45, 583-593.

Hillensjö, T. (1976) Oocyte maturation and glycolysis in isolated preovulatory follicles of PMS-injected immature rats. Acta endocr., Copenh. 82, 809-830.

Hillensuö, T., Bauminger, S. \& Ahrén, K. (1976a) Effect of luteinizing hormone on the pattern of steroid production by preovulatory follicles of pregnant mare's serum gonadotropin-injected immature rats. Endocrinology 99, 996-1002.

Hillensjö, T., Deket, N. \& Ahrén, K. (1976b) Effects of gonadotropins on the cumulus oophorus of isolated rat graafian follicles. Acta physiol. scand.96, 558-568.

Hopkinson, C. \& PaNT, H.C. (1973) Heterologous radioimmunoassay of circulating ovine FSH in normal ewes. J. Physiol., Lond. 231, 52P-53P.

HuNTER, R.H.F. \& POLge, C. (1966) Maturation of follicular oocytes in the pig, after injection of human chorionic gonadotrophin. J. Reprod. Fert. 12, 525531.

HuNTER, R.H.F., LAwson, R.A.S. \& Rowson, L.E.A. (1972) Maturation, transplantation and fertilization of ovarian oocytes in cattle.J. Reprod. Fert. 30, 325328.

Hunter, R.H.F, Cook, B. \& BaKeR, T.G. (1976) Dissociation of response to injected gonadotrophin between the Graafian follicle and oocyte in pigs. Nature, Lond. 260, 156-158. 
Hunzicker-DunN, M. \& Birngaumer, L. (1976a) Adenyl-cyclase activities in ovarian tissues. III. Regulation of responsiveness to LH, FSH and PGE in the prepubertal, cycling, pregnant and pseudopregnant rat. Endocrinology 99, 198-210.

Hunzicker-DunN, M. \& Birnbaumer, L. (1976b) Adenyl-cyclase activities in ovarian tissues. IV. Gonadotropin-induced desensitization of the luteal adenyl-cyclase throughout pregnancy in the rabbit and the rat. Endocrinology 99, 211-222.

Iwamatsu, T. \& YaNagimachI, R. (1975) Maturation in vitro of ovarian oocytes of prepubertal and adult hamsters. J. Reprod. Fert. 45, 83-90.

Jacobelli, S., Hanoce, J., Baltus, E. \& Brachet, J. (1974) Hormone induced maturation of Xenopus laevis oocytes; effects of different steroids and study on the properties of a progesterone receptor. Differenciation 2, 129-135.

Jagiello, G., Ducayen, M., Miller, W., Graffeo, J. \& FANG, J.S. (1975) Stimulation and inhibition with $\mathrm{LH}$ and other hormones of female mammalian meiosis in vitro. J. Reprod. Fert. 43, 9-22.

JALABERT, B. (1976) In vitro maturation and ovulation in rainbow trout (Salmo gairdneri) northern pike (Esox lucius) and goldfish (Carassius auratus). J. Fish. Res. Board Can. 33, 974-988.

JALABERT, B. \& SzölLöst, D. (1975) In vitro ovulation of trout oocytes: effects of prostaglandins on smooth muscle-like cells of the theca. Prostaglandins 9, 765778.

JALABERT, B., Breton, B., Brzuska, E., Fostier, A. \& WiENIAWskr, J. (1977) A new tool for induced spawning; the use of $17 \alpha$-hydroxy-20ß-dihydroprogesterone to spawn carp at low temperature. Aquacultura 10, 353-364.

Kennedy, J.F. \& Donahue, R.P. (1969) Human oocytes: maturation in chemically defined media. Science, N.Y. 164, 1292-1293.

L'Hermite, M., Niswender, G.D., Reichert, L.E. \& Midgley, A.R. (1972) Serum follicle-stimulating hormone in sheep as measured by radioimmunoassay. Biol. Reprod. 6, 325-332.

LIeberman, M.E., AHréN, K., TSAFriri, A., Bauminger, S. \& LINDNER, H.R. (1975) Relationship between glycolysis and steroidogenesis in cultured graafian follicles stimulated by $\mathrm{LH}$ or prostaglandin $\mathrm{E}_{2}$. J. Steroid Biochem. 6, 1445-1449.

Lieberman, M.E., Tsafriri, A., Bauminger, S., Collins, W.P., Ahrén, K. \& Lindner, H.R. (1976) Oocytic meiosis in cultured rat follicles during inhibition of steroidogenesis. Acta endocr., Copenh. 83, 151-157.

Lintern-Moore, S., Peters, H., Moore, G.P.M. \& FABER, M. (1974) Follicular development in the infant human ovary. J. Reprod. Fert. 39, 53-64.

Louvet, J.P. \& VAITUKAITIS, J.C. (1976) Induction of follicle-stimulating hormone (FSH) receptors in rat ovaries by estrogen priming. Endocrinology 99, 758764.

MAHI, C.A. \& YANAGIMACHi, R. (1976) Maturation and sperm penetration of canine ovarian oocytes. J. exp. Zool. 196, 189-196.

Mandelbaum, J., Plachot, M. \& Thibault, C. (1977) Role of the follicle in final zona pellucida maturation of hamster oocyte. Annls Biol. anim. Biochim. Biophys. 17, 389-391.

McNatty, K.P., Hunter, W.M., McNeilly, A.S. \& SAWERs, R.S. (1975) Changes in the concentration of pituitary and steroid hormones in the follicular fluid of human Graafian follicles throughout the menstrual cycle. J. Endocr. 64, 555-571.

Menezo, Y. (1976) Milieu synthétique pour la survie et la maturation des gamètes et pour la culture de l'oeuf fécondé. C. r. hebd. Séanc. Acad. Sci., Paris 282, 1967-1970.

Menezo, Y., Gerard, M. \& Thibault, C. (1976a) Attempts at in vitro fertilization in calf. In Egg Transfer in Cattle, pp. 189-198. Ed. L.E.A. Rowson. Commission European Communities, Luxembourg.

Menezo, Y., Gerard, M. \& Thibault, C. (1976b) Culture du follicule de de Graaf de bovin dans un système à courant liquide et gazeux continu. $C$. $r$. hebd. Séanc. Acad. Sci., Paris 283, 1309-1311.

Merchant, H. \& Chang, M.C. (1971) An electron microscopic study of mouse eggs maturated in vivo and in vitro. Anat. Rec. 171, 21-38.

Merk, F.B., Botticelli, C.R. \& Albright, J.T. (1972) An intercellular response to estrogen by granulosa cells in the rat ovary: an electron microscope study. Endocrinology 90, 992-1007.

Miller, W.A. \& Jagiello, G. (1973) Gonadotropin dependency of isolated ovine ovarian follicles cultured in vitro. Fert. Steril. 24, 609-617.

Moor, R.M. \& Trounson, A.O. (1977) Hormonal and follicular factors affecting maturation of sheep oocytes in vitro and their subsequent developmental capacity. J. Reprod. Fert. 49, 101-109.

Moricard, R. (1968) Gonadotropines, méiose, ovulation. Cytophysiologie et applications humaines. II. Fonction méiogène du liquide folliculaire. Microscopie électronique. Ovocyte de Lapine et de Souris. Ovocyte humain. Rev. Franç, Gynec. 63, 501-539.

Motlik, J. \& FulkA, J. (1974a) Fertilization of pig follicular oocytes cultivated in vitro. J. Reprod. Fert. 36, 235-237.

Motlik, J. \& FulkA, J. (1974b) Fertilization and development in vivo of rabbit oocytes cultivated in vitro. J. Reprod. Fert. 40, 183-186.

Motı,ik, J. \& FulkA, J. (1976) Breakdown of the germinal vesicle in pig oocytes in vivo and in vitro. J. exp. Zool. 198, 155-162.

Mukherjee, A.B. (1972) Normal progeny from fertilization in vitro of mouse oocytes matured in culture and spermatozoa capacitated in vitro. Nature, Lond. 237, 397-398.

Nicosia, S.V. \& Mikhail, G. (1975) Cumuli oophori in tissue culture: hormone production, ultrastructure and morphometry of early luteinization. Fert. Steril. 26, 427-448.

Niwa, K. \& Chang, M.C. (1975) Fertilization of rat eggs in vitro at various times before and after ovulation with special reference to fertilization of ovarian oocytes matured in culture. J. Reprod. Fert. 43, 435-451.

Niwa, K., MiYake, M., Iritani, A. \& Nishikawa, Y. (1976) Fertilization of rat oocytes cultured in vitro from various stages of maturation. J. Reprod. Fert. $47,105-106$. 
Ozon, R. \& Bellé, R. (1973) Progesterone receptor associated with melanosome fraction of Pleurodeles waltlii oocytes. Biochim. biophys. Acta 320, 588-593.

PANT, H.C., Hopkinson, C.N.R. \& Fitzpatrick, R.J. (1977) Concentration of oestradiol, luteinizing hormone and follicle-stimulating hormone in the jugular venous plasma of ewes during the oestrous cycle. J. Endocr. 73, 247-255.

Plachot, M. \& Mandelbaum, J. (1977) Non fécondabilité de l'ovocyte de hamster maturé in vitro. $C . r$. hebd. Séanc. Acad. Sci., Paris 284, 953-955.

QUIRKE, J.F. \& GORDON, I. (1971) Culture and fertilization of sheep ovarian oocytes. I. Effects of culture medium on resumption of meiosis. J. agric. Sci., Camb. 76, 369-372.

Remacle, C., Delaere, P. \& Jacquet, P. (1976) Actions hormonales sur les cellules germinales femelles de Carassius auratus en culture organotypique. Renversement sexuel et ovogenèse in vitro. Gen. comp. Endocr. 29, 212-224.

Richards, J.S. \& Midgley, A.R. (1976) Protein hormone action: a key to understanding ovarian follicular and luteal cell development. Biol. Reprod. 14, 82-94.

Salamonsen, L.A., Jonas, H.A., Burger, H.G., Buckmaster, J.M., Chamley, W.A., Cumming, I.A., FindLAY, J.K. \& GodiNG, J.R. (1973) A heterologous radioimmunoassay for follicle-stimulating hormone: application to measurement of FSH in the ovine estrous cycle and in several other species including man. Endocrinology 93, 610-618.

Sanyal, M.K. \& Sibre, E.R. (1973) Breakdown of germinal vesicle of frog oocytes with $5 \alpha$ reduced products of progesterone in vitro. Proc. Soc. exp. Biol. Med. 144, 483-486.

Schams, D. \& Schallenberger, E. (1976) Heterologous radioimmunoassay for bovine follicle stimulating hormone and its application during the estrous cycle in cattle. Acta endocr., Copenh. 81, 461-473.

Schuetz, A.W. (1972) Hormones and follicular functions. In Oogenesis, pp. 479-511. Eds J. Biggers \& A. W. Schuetz. University Park Press, Baltimore.

Seamark, R.F., MoOR, R.M. \& McIntosh J.E.A. (1974) Steroid hormone production by sheep ovarian follicles cultured in vitro. $J$. Reprod. Fert. 41, 143-158.

SheA, B.F., BAKeR, R.D. \& LATOUR, J.P.A. (1975) Human follicular oocytes and their maturation in vitro. Fert. Steril. 26, 1075-1082.

Shea, B.F., LATour, J.P.A., Bedirian, K.N. \& BaKer, R.D. (1976) Maturation in vitro and subsequent penetrability of bovine follicular oocytes. J. Anim. Sci. 43, 809-815.

Smrth, L.D., Ecker, R.E. \& Subtelny, S. (1968) In vitro induction of physiological maturation in Rana pipiens oocytes removed from their ovarian follicles. Devl Biol. 17, 627.

Sorensen, R.A. \& Wassarman, P.M. (1976) Relationship between growth and meiotic maturation of the mouse oocyte. Devl Biol. 50, 531-536.

SOUPART, P. (1973) The need for capacitation of human sperm; functional and ultrastructural observations. In Biology of Spermatozoa. Transport, Survival and Fertilizing Ability, vol. 26, pp. 407-434. Eds E. S. E. Hafez \& C. Thibault. Inserm. Paris.
SOUPART, P. (1974) The need for capacitation of human sperm; functional and ultrastructural observations. In Biology of Spermatozoa, pp. 182-191. Eds E. S. E. Hafez \& C. Thibault. Karger, Basle.

SREENAN, J. (1970) In vitro maturation and attempted fertilization of cattle follicular oocytes. J. agric. Sci., Camb. 75, 393-396.

Suzuki, S. \& MastrolanNi, L. (1966) Maturation of monkey ovarian follicular oocytes in vitro. Am. J. Obstet. Gynec. 96, 723-731.

Swartz, W.J. \& Schuetz, A.W. (1975) Morphological diversity of oocytes released from the adult mouse ovary. Am. J. Anat. 144, 365-372.

SzyBEK, K. (1972) In vitro maturation of oocytes from sexually immature mice. $J$. Endocr. 54, 527-528.

Thibault, C. (1972) Final stages of mammalian oocyte maturation. In Oogenesis, pp. 397-411. Eds J. D. Biggers \& A. W. Schuetz. University Park Press, Baltimore.

Thibault, C. \& Gfrard, M. (1970) Facteur cytoplasmique nécessaire à la formation du pronucleus mâle dans l'ovocyte de Lapine. $C$. r. hebd. Séanc. Acad. Sci., Paris 270, 2025-2026.

Thibault, C. \& Gérard, M. (1971) Maturation et fécondation in vitro de l'ovocyte de la Lapine. In Malformations Congénitales, pp. 13-25. Ed. R. Tuchmann-Duplessis. Masson, Paris.

Thibault, C. \& Gérard, M. (1973) Cytoplasmic and nuclear maturation of rabbit oocytes in vitro. Annls Biol. anim. Biochim. Biophys. 13, 145-156.

Thibault, C., Ortavant, R. \& Laplaud, M. (1948) Recherches sur la superovulation expérimentale chez la Brebis. Annls Endocr. 9, 83-89.

Thibault, C., Gérard, M. \& Menezo, Y. (1975a) Preovulatory and ovulatory mechanisms in oocyte maturation. J. Reprod. Fert. 45, 605-610.

Thibault, C., Gérard, M. \& Menezo, Y. (1975b) Acquisition par l'ovocyte de Lapine et de Veau du facteur de décondensation du noyau du spermatozoide fécondant (MPGF). Annls Biol. anim. Biochim. Biophys. 15, 705-714.

Thibault, C., Gérard, M. \& Menezo, Y. (1976) Nuclear and cytoplasmic aspects of mammalian oocyte maturation in vitro in relation to follicle size and fertilization. In Sperm action. Prog. Reprod. Biol. 1, 233-240.

Thibier-Fouchet, C., Mulner, O. \& Ozon, R. (1976) Progesterone biosynthesis and metabolism by ovarian follicles and isolated oocytes of Xenopus laevis. Biol. Reprod. 14, 317-326.

Tsafriri, A. \& Channing, C. (1975a) Influence of follicular maturation and culture conditions on the meiosis of pig oocytes in vitro. J. Reprod. Fert. 43, 149-152.

TSAFRIRI, A. \& Channing, C.P. (1975b) An inhibitory influence of granulosa cells and follicular fiuid upon porcine oocyte meiosis in vitro. Endocrinology 96, 922-927.

TSAFRIRI, A., LINDNER, H.R., ZOR, U. \& LAMPRECHT, S.A. (1972) In vitro induction of meiotic division in follicle enclosed rat oocytes by $\mathrm{LH}$, cyclic AMP and prostaglandin $\mathrm{E}_{2}$.J. Reprod. Fert. 31, 39-50. 
TSAfriri, A., Lieberman, M.E., Ahrén, K. \& LindNer, H.R. (1976) Dissociation between LH-induced aerobic glycolysis and oocyte maturation in cultured Graafian follicles of the rat. Acta endocr., Copenh. 81, 363-366.

USUI, N. \& YANAGIMACHI, R. (1976) Behavior of hamster sperm nuclei incorporated into eggs at various stages of maturation, fertilization, and early development. J. Ultrastruct. Res. 57, 276-288.

Warnes, G.M., MoOR, R.M. \& JoHnson, M.H. (1977) Changes in protein synthesis during maturation of sheep oocytes in vivo and in vitro.J. Reprod. Fert. 49, 331-335.

WELSCHEN, R. (1972) Effect of unilateral ovariectomy on follicular growth in hypophysectomized rats treated with pregnant mare serum gonadotrophins. $J$. Endocr. 55, 227-228.

Welschen, R. \& DullaART, J. (1974) Serum concentrations of follicle stimulating hormone and luteinizing hormone after unilateral ovariectomy in the adult rat. $J$. Endocr. 63, 421-422.

WeLSCHEN R. \& DULlaART, J. (1976) Administration of antiserum against ovine follicle stimulating hormone or ovine luteinizing hormone at pro-oestrus in the rat: effects on follicular development during the oncoming cycle. $J$. Endocr. 70, 301-306.

Welschen, R., Osman, P., Dullaart, J., De Greef, W.J., UilenbroeK, J.TH.J. \& DE JONG, F.H. (1975) Levels of follicle-stimulating hormone, luteinizing hormone, oestradiol-17 $\beta$ and progesterone, and follicular growth in the pseudopregnant rat. J. Endocr. 64, 37-47.

Wide, L., Nillius, S.J., Gemzell, C. \& Roos, P. (1973) Radioimmunosorbentassay of follicle-stimulating hormone and luteinizing hormone in serum and urine from men and women. Acta endocr., Copenh., Suppl. 174.

YANAGIMACHI, R. (1974) Maturation and fertilization in vitro of guinea-pig oocytes. J. Reprod. Fert. 38, 485488.

Zeilmaker, G.H. \& Verhamme, C.M. (1974) Observations on rat oocyte maturation in vitro: morphology and energy requirements. Biol. Reprod. 11, 145-152.

Zeilmaker, G.H., Hulsmann-Wensinck, F. \& VeRHAMme, C.M. (1972) Oxygen-triggered mouse oocyte maturation in vitro and lactate utilization by mouse oocytes and zygotes. J. Reprod. Fert. 29, 151152.

Zelesnik, A.J., Midgley, A.R., Jr \& Reichert, L.E., Jr (1974) Granulosa cell maturation in the rat: increased binding of human chorionic gonadotropin following treatment with follicle stimulating hormone in vivo. Endocrinology 95, 818-825.

Zor, U., LAMPrecht, S.A., Misulovin, Z., Kock, Y. \& LINDNER, H.R. (1976) Refractoriness of ovarian adenylate cyclase to continued hormonal stimulation. Biochim. biophys. Acta 428, 761-765. 